DOI 10.37882/2223-2982.2021.01-2.05

\title{
ПРИМЕНЕНИЕ ПРИНЦИПОВ КООПЕРАЦИИ И ВЕЖЛИВОСТИ В РЕЧЕВОЙ КОММУНИКАЦИИ НОСИТЕЛЕЙ РУССКОГО И КИТАЙСКОГО ЯЗЫКОВ
}

\section{APPLICATION OF THE PRINCIPLES OF COOPERATION AND POLITENESS IN SPEECH COMMUNICATION OF NATIVE SPEAKERS OF RUSSIAN AND CHINESE LANGUAGES}

Wang Dihan

Summary: The article investigates the application of the principles of cooperation and courtesy of people who speak Russian and Chinese, which is relevant for the analysis of the speech behavior of communicants of different cultures. Analyzing different understandings of the principle of politeness by Chinese scientists and scientists of other countries, the author came to the conclusion: the principle of politeness is an addition to the principle of cooperation, in order to achieve a communicative goal, communicants should be more flexible and worthy of using these two important principles, taking into account factors such as language area, context, and cultural differences.

Keywords: speech communication, the principle of cooperation, the principle of politeness, speech behavior.

\section{Приншипы кооперашии Г.П. Грайса}

$\mathrm{B}$ 1967г. американский лингвист и философ Г.П. Грайс в своем выступлении в Гарвардском университете на тему «Логика и речевое общение», в процессе которого им был предложен принцип кооперации. Он отметил, что в нормальных коммуникативных ситуациях люди всегда кооперируются, чтобы достигнуть единой цели общения, то есть предоставляют друг другу информацию, необходимую для того, чтобы разговор прошел в соответствии с целью или выбранным направлением общения (Г.П. Грайс, 1997). Например, утром жена спрашивает мужа: "Что ты будешь на завтрак?" А муж отвечает: «Сегодня погода хорошая». Очевидно, что в этом разговоре муж не предоставил информацию, необходимую для жены, и не соблюдал принцип кооперации, то есть их разговор был обречен на провал. Г.П. Грайс предложил четыре составляющие принципа кооперации:

1. максима количества (полноты) информации: высказывание должно содержать не меньше информации, чем требуетс; высказывание не должно содержать больше информации, чем требуется.

2. максима качества информации: предоставленная информация верна (не говорите того, что счита-
Ван Дихань

Аспирант, Московский государственный университет имени М.В. Ломоносова wangdihan@inbox.ru

Аннотация: В статье проводится исследование применения принципов кооперации и вежливости людей носителей русского и китайского языков, которое имеет актуальное значение для анализа речевого поведения коммуникантов разных культур. Анализируя разные понимания принципа вежливости китайским ученым и учеными других стран, автор пришел к выводу: принцип вежливости является дополнением к принципу кооперации, для достижения коммуникативной цели, коммуниканты должны быть более гибкими и достойны использования этих двух важных принципов, принимая во внимание такие факторы, как языковая область, контекст и культурные различия.

Ключевые слова: речевая коммуникация, принцип кооперации, принцип вежливости, речевое поведения.

ешь ложным; не говорите того, для чего у вас нет достаточных оснований);

3. максима отношения (релевантности): предоставленная информация должна соответствовать предмету разговора;

4. максима способа выражения (манеры): предоставленная информация должна быть понятной (необходимо избегать непонятных выражений; избегать неоднозначности; быть кратким; речь должна быть организованной).

Основываясь на этих составляющих принципа кооперации, мы можем научиться использовать разумные речевые обороты для общения и достижения коммуникативных целей. Но данные составляющие принципа условны и не являются абсолютно непреодолимыми. Говорящие иногда не соблюдают эти принципы из вежливости. Вежливость ограждает говорящего от откровений в разговоре, поэтому в повседневном речевом общении мы также должны помнить и соблюдать принцип вежливости.

\section{Приншип вежкивости}

Принцип вежливости был впервые предложен бри- 
танским ученым Дж. Личем в 1983 году, а затем в 1992 году китайский ученый Гу Юэйгуо предложил принцип вежливости, применимый в соответствие с культурой и традицией Китая.

\section{1. Приншип вежливости за рубежом}

По мнению Дж. Лича, принцип кооперации и принцип вежливости дополняют друг друга. Принцип вежливости состоит из шести принципов:

1. максима такта: это максима границ личной сферы. В идеале любой коммуникативный акт предусматривает определенную дистанцию. Не следует затрагивать тем, потенциально опасных (частная жизнь, индивидуальные предпочтения и пр.);

2. максима великодушия: успешный коммуникативный акт не должен быть дискомфортным для участников общения. Не следует связывать партнера обещанием или клятвой;

3. максима одобрения: стараться меньше унижать других, больше хвалить других;

4. максима скромности: старайтесь как можно меньше хвалить себя и умалять себя;

5. максима согласия: минимизируйте разногласия между двумя сторонами, увеличивайте их согласие;

6. максима симпатии: минимизируйте отвращение к другим и увеличивайте сочувствие к другим.

Из вышеприведенных шести принципов мы видим, что говорящий должен стараться вести себя скромно, больше уважать и хвалить других, чтобы обе стороны общения чувствовали уважение друг к другу, чтобы достичь цели общения и способствовать успеху речевого общения. Конечно, люди не должны соблюдают принцип вежливости всегда и везде. В срочных, неожиданных ситуациях, в спорах, в общении с близкими, принцип вежливости часто имеет второстепенное значение.

\section{2. Приншип вежливости в Китае}

В 1992 году китайский ученый Гу Юэйгуо предложил пять составляющих принципа вежливости, применимого в соответствии с традицией и культурой Китая:

1. “自卑而尊人”与贬己尊人准则(Восхваление собеседника и «самоунижение»): говорящие должны быть смиренными и скромными в беседе о личных делах, хвалить собеседника и принижать свои заслуги;

2. “上下有义，贵贱有分，长幼有等”与称呼准则(Coответствие обращения социальному статусу собеседника): обращение к людям должно быть основано на их социальном статусе;

3. “涁涁有礼” 与文雅准则(Использование манер и культурной речи): при общении люди должны говорить культурно, соблюдая манеры. Посред- ственная, простая речь исключена.

4. “脸” “面子”与求同准则 (Уважение и стремление к единству): когда мнение говорящего и слушателя расходятся во время общения, они должны уметь уступать друг другу, т.е. стремиться к компромиссу, сохраняя свои взгляды;

5. “有德者必有言”与德、言、行准则(Скромность и оценка поступков собеседника): Когда разговор касается поступков говорящего, их целью должна являться польза для окружающих. Однако во время общения, говорящий не может восхвалять себя, преувеличивая свои заслуги, стараясь, наоборот, выделить преимущества собеседника, оценивая по достоинству его поступки. (Гу Юэйгуо, 1992).

Анализируя принцип вежливости в зарубежных странах и в Китае, мы можем сделать вывод, что составляющие "максима одобрения" и "максима согласия", предложенный Дж. Личем, имеет сходство с составляющей "уважение и стремление к единству", предложенной китайскими учеными. Основное различие между принципами вежливости Китая и западных стран заключается в восхваление собеседника и «самоунижения», который отражает характер китайской культуры.

Применение принципа кооперации и принципа вежливости в речевой коммуникации носителей китайского и русского языков.

Принцип кооперации и принцип вежливости широко применяются в повседневной жизни людей. Культурные различия часто приводят к разному пониманию речевого поведения, особенно в межкультурной коммуникации. Ориентирование на различия применения принципов кооперации и вежливости как в Китае и России по отдельности, так и в международном общении, является актуальным с точки зрения развития дружественных отношений между обеими странами.

Проанализируем три диалога:

1) (Китайская девушка А разговаривает со своей русской подругой Б в коридоре.)

A: - Ты сегодня очень красивая!

Б: - Спасибо! Ты тоже.

A: - Нет, нет.

В этой мини сценке А оценила внешность своей подруги, в ответ Б тоже дала свою положительную оценку А. Обе собеседницы соблюдали максиму одобрения. Получив одобрение Б, А ответила отрицательно, что является непонятным и странным для иностранцев действием. Очевидно, А нарушила такую составляющую принципа коммуникативности, как максима качества информации, так как она вряд ли считает себя некрасивой, что делает её отрицательный ответ ложной информацией. Однако, 
согласно принципу вежливости в Китае А соблюдала такую его составляющую, как восхваление собеседника и «самоунижения», совпадающий с максимой скромности принципа вежливости Дж. Лича. Китайцы считают самоунижение проявлением высоких нравственных качеств, они привыкли отрицать одобрение к себе со стороны окружающих и считают такое отрицание способом выражения вежливости. Для русских распространенным ответом является «спасибо», но не самоунижение.

2) (Китайский студент попросил своего преподавателя проверить его научную работу.)

Студент: 请老师帮我看一下文章。(Преподаватель, прошу вас, проверьте мою работу.)

Преподаватель: 好的。(Хорошо.)

Студент: 辛苦了! (Вы утомитесь!)

В данном диалоге студент и преподаватель соблюдали принцип кооперации Г.П. Грайса: студент попросил преподавателя проверить работу, четко выразив цель разговора (максима способа выражения), и преподаватель принял просьбу (максима отношения). Однако, если дословно перевести этот диалог на русский язык, для русскоговорящих он станет несколько непонятным. Дело в том, в России принято обращаться к преподавателям по имени и отчеству, а в Китае произнесение имени старших или людей более высокого социального статуса считается неприличным и невежливым. Китайцы обычно используют сочетание должности и фамилии для обращения к старшим или людям более высокого социального статуса. Поэтому в данном диалоге студент соблюдал китайский принцип вежливости, а именно соответствие обращения социальному статусу собеседника. Следует также отметить, что вместо благодарности студент ответил «Вы утомитесь». Такое выражение очень часто встречается в китайском языке. Это, некоторым образом, нарушает принцип кооперации Г.П. Грайса (максиму отношения, максиму качества и количества информации), но совпадает с китайским принципом вежливости с выражающегося че- рез скромность и оценку поступков собеседника. При помощи оценки поступков собеседника и принесения извинений за беспокойство, китайцы выражают свою благодарность к другим.

3) (Китаец увидел своего соседа на улице)

Китаец: 你去哪啊? 你吃了吗? (Куда ты идешь? Покушал?)

Сосед: 吃了，现在去学校接女儿。(Да, покушал， сейчас иду встречать дочку из школы.)

Известно, что у китайцев принято спрашивать “你 吃了吗?" (Ты покушал?) вместо «привет» или «как дела?». Такой вопрос нарушает принцип вежливости Дж. Лича (максиму такта). По мнению Дж. Лича, при общении люди не должны затрагивать тем, касающихся какихлибо личных моментов жизни собеседника. В России и во многих иностранных государствах прием пищи - это личное дело. Если кто-то спрашивает об этом собеседника, значит он хочет пригласить его на обед либо имеет какую-либо иную цель. Без последующего целевого контекста такой вопрос считается неприличным.

Кооперация и вежливость - это, как правило, общие явления для всех социальных групп. Они представляют собой инструменты поддержания межличностной гармонии, сдерживающие людей от излишней прямоты и откровенности в процессе общения. Принцип кооперации и принцип вежливости - два важных принципа, которым должны следовать обе стороны речевого общения. Принцип вежливости является дополнением к принципу кооперации и оба эти принципа имеют взаимные уступки. При общении принцип вежливости игнорируется, если обе стороны уделяют больше внимания принципу кооперации. Если используется принцип вежливости, принцип кооперации отступает на второй план. Это приводит к выводу, что в процессе общения собеседники должны стараться лавировать, применяя в нужной мере оба этих принципа, учитывая языковые и культурные различия Китая и России.

\section{ЛИТЕРАТУРА}

1. Гойхман 0.Я., Надеина Т.М. Речевая коммуникация. - М.: ИНФРА, 2008.

2. Grice, H. P. Logic and Conversation. In Cole \& Morgan ( eds. ). Syntax and Semantics Vol.3: Speech Acts. New York: Academic Press, 1975.

3. Leech, G. Principles of Pragmatics. New York: Logman Inc, 1983.

4. 顾曰国. 礼貌、语用和文化. 外语教学与研究， 1992, 28(4)：10-17. [Гу Юэйгуо. Вежливость, прагматика и культура. - Шанхай: Преподавания и исследования иностранных языков, 1992, 28(4). С.10-17].

5. 何自然. 新编语用学概论. 北京：北京大学出版社，2010. [Хэ Цзыжань. Новая редакция общего введения в прагматическую лингвистику. Пекин: Пекинский университет, 2010].

(c) Ван Дихань (wangdihan@inbox.ru). 